\title{
Aplikasi Asam Humat Hasil Isolasi Tanah Gambut Kalimantan sebagai Adsorben Zat Warna Naphtol Blue Black dan Indigosol Blue: Studi Perbandingan Model Kinetika dan Isoterm Adsorpsi
}

\author{
Maya Rahmayanti*1, Masyithah Nisvi Prandini ${ }^{2}$, Gita Citra Santi ${ }^{3}$ \\ ${ }^{1,2,3}$ Program Studi Kimia, Fakultas Sains dan Teknologi, Universitas Islam Negeri Sunan \\ Kalijaga Yogyakarta, Yogyakarta, Indonesia \\ *Email: maya.rahmayanti@uin-suka.ac.id
}

\begin{abstract}
A comparative study of kinetic and isotherm adsorption models of naphtol blue black (NBB) and indigosol blue (IB) dyes adsorption onto humic acid (HA) isolated from Kalimantan peat soils has been carried out. Adsorption of NBB and IB in HA follows the second order Ho kinetics model, with the reaction rate constant of NBB adsorption onto HA higher than the the reaction rate constant of IB adsorption onto HA. Studi of adsorption isotherm showed that the adsorption of $N B B$ and IB in HA follows the Langmuir isotherm model with the maximum adsorption capacity of NBB and IB in HA respectively $0.12 \times 10^{-4}$ and $1.04 \times 10^{-4} \mathrm{~mol} / \mathrm{g}$.
\end{abstract}

Keywords : naphtol blue black, indigosol blue, humic acid, adsorption kinetic, adsorption isoterm

\begin{abstract}
Abstrak
Studi perbandingan model kinetika dan isoterm adsorpsi zat warna naphtol blue black (NBB) dan indigosol blue (IB) pada asam humat (HA) hasil isolasi tanah gambut Kalimantan telah dilakukan. Adsorpsi NBB dan IB pada HA mengikuti model kinetika orde dua Ho, dengan konstanta laju reaksi adsorpsi NBB pada HA lebih tinggi dibandingkan konstanta laju reaksi adsorpsi IB pada HA. Studi isoterm reaksi menunjukkan bahwa adsorpsi NBB dan IB pada HA mengikuti model isoterm Langmuir dengan kapasitas adsorpsi maksimum NBB dan IB pada HA berturut-turut adalah $0,12 \times 10^{-4}$ dan $1,04 \times 10^{-4} \mathrm{~mol} / \mathrm{g}$.
\end{abstract}

Kata kunci : naphtol blue black, indigosol blue, asam humat, kinetika adsorpsi, isoterm adsorpsi

\section{Pendahuluan}

Penggunaan zat warna sintetis pada industri batik masih belum bisa dilepaskan. Beberapa kelebihan zat warna sintesis antara lain mudah didapatkan, murah, warna yang dihasilkan lebih kuat dan tahan lama, dan ketersediaan jenis warna yang lebih variatif. Penggunaan zat warna dalam industri batik menimbulkan permasalahan lingkungan yang berasal dari limbah cair pewarnaan. Dalam proses pewarnaan batik, hanya sekitar $45 \%$ zat warna yang tertempel pada kain batik, sisanya terbuang pada proses pencucian [1]. Zat warna sintesis memiliki sifat non-biodegradable, toksik dan kelarutan yang tinggi [2]. Zat warna sintetis yang paling banyak digunakan oleh industri batik adalah naphtol blue black (NBB) dan indigosol blue (IB). Zat warna NBB memiliki ketahanan warna yang tinggi pada kain batik, namun dapat menghasilkan produk samping yang bersifat mutagenik dan karsinogenik [3]. Begitu pula dengan zat warna IB dapat menghasilkan produk samping yang bersifat toksik [4]. Hal inilah yang menyebabkan zat warna sintetis yang terkandung di dalam limbah cair batik sangat berbahaya jika langsung di buang ke badan air tanpa pengolahan terlebih dulu. 
Berbagai metode pengolahan zat warna sintetis sudah banyak dilaporkan, seperti metode koagulasi, flokulasi, ozonisasi, elektrokimia, oksidasi dan fotokatalisis, serta pengolahan secara biologi menggunakan bakteri. Metode-metode yang sudah dilakukan tersebut memiliki beberapa kelemahan, misalnya metode ozonisasi memerlukan biaya yang tinggi dan sukar untuk diterapkan dalam industri batik. Metode koagulasi dan filtrasi menghasilkan lumpur (sludge) dalam jumlah yang relatif besar. Pengolahan secara biologi seringkali gagal dikarenakan bakteri tidak mampu beradaptasi dengan kompleksitas zat warna. Kelemahan metode elektrokimia adalah membutuhkan biaya listik yang tinggi sehingga tidak efektif diterapkan pada industri batik. Berdasarkan kekurangan-kekurangan metode di atas, metode adsorpsi menggunakan bahan alam yang tersebar di Indonesia menjadi pilihan. Selain murah dan cepat, metode adsorpsi dapat diterapkan secara sederhana pada industri batik. Selain itu, adsorben yang digunakan dapat diregenerasi dengan melakukan proses desorpsi sehingga adsorben dan adsorbat dapat digunakan kembali.

Aplikasi adsorben asam humat sudah banyak dilaporkan berhasil dalam menurunkan kandungan zat warna dalam limbah simulasi maupun limbah asli [1,5-9]. Asam humat (HA) merupakan fraksi senyawa humat yang terkandung dalam tanah gambut. Asam humat memiliki kandungan gugus $-\mathrm{COOH}$ dan $-\mathrm{OH}$ yang melimpah yang dapat berperan sebagai situs aktif dalam mengadsorpsi adsorbat termasuk zat warna [10]. Interaksi antara asam humat dengan adsorbat dapat terjadi melalui interaksi elektrostatik, pembentukan kelat, pertukaran ion dan ikatan hidrogen [11-13].

Pada penelitian ini, asam humat diaplikasikan sebagai adsorben zat warna NBB dan IB yang biasa dipakai oleh industri batik Yogyakarta. Model kinetika dan isoterm adsorpsi NBB dan IB pada HA akan dipelajari dan dibandingkan.

Zat warna NBB yang digunakan dalam industri batik merupakan zat warna azo yang mempunyai dua komponen dasar, yaitu asam anilat dan pembangkit warna garam diazonium. Gabungan dua komponen menghasilkan senyawa berwarna[20]. Untuk menghasilkan warna, NBB yang tidak larut di dalam air harus ditambahkan soda kustik dan direaksikan dengan garam blue black.

\section{Metoda Penelitian \\ 2.1. Alat dan Bahan}

Alat yang digunakan pada penelitian ini antara lain satu paket alat gelas standar laboratorium, kertas Whatman 42, indikator pH universal, neraca analitik, spatula,dan Spektrofotometer UV-Vis 1800 Double Beam Shimadzu.

Adsorben yang digunakan pada penelitian ini adalah asam humat siap pakai hasil isolasi tanah gambut Kalimantan yang berbentuk serbuk (struktur senyawa asam humat disajikan pada Gambar 1). Adsorbat yang digunakan adalah zat warna NBB dan IB khusus pewarna batik (struktur senyawa NBB dan IB disajikan pada Gambar 2 dan 3. Bahan pendukung yang digunakan antara lain $\mathrm{HCl}$, $\mathrm{NaOH}$, dan akuades berkualitas analitik (analytical grade) buatan E Merck.

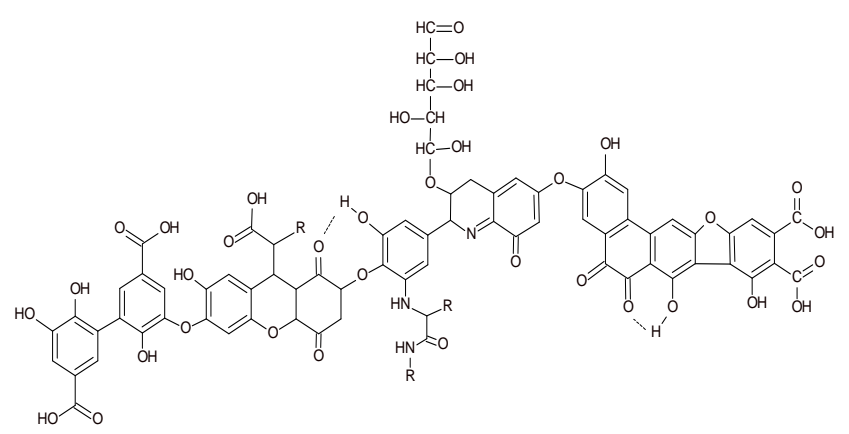

Gambar 1. Struktur kimia hipotesis asam humat hasil isolasi tanah gambut Kalimantan [1]

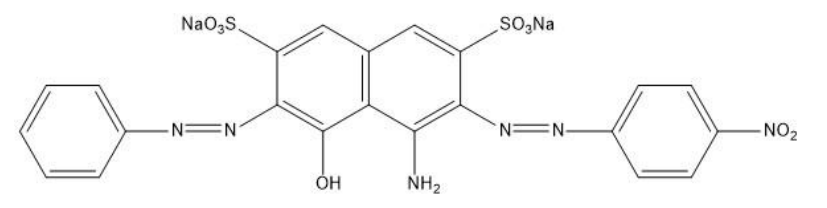

Gambar 2. Struktur kimia NBB 


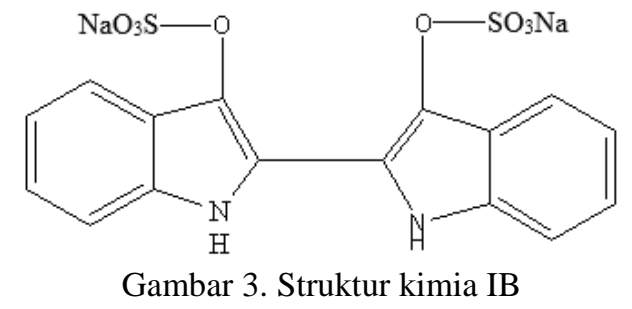

\subsection{Penentuan Panjang Gelombang Maksimum NBB dan IB Menggunakan Spektofotometri UV-Vis}

Panjang gelombang maksimum NBB dan IB ditentukan dengan mengukur larutan NBB dan IBpada rentang panjang gelombang 400-800 nm dengan menggunakan spektrofotometri UV-Vis. Panjang gelombang yang memiliki nilai absorbansi terbesar merupakan panjang gelombang maksimum. Larutan NBB dibuat dengan cara melarutkan naphtol pada larutan soda kustik dan ditambahkan garam blue black sebagai larutan pembangkit warna. Sementara larutan indigosol blue dilarutkan menggunakan akuades saja.

\subsection{Pembuatan Kurva Standar Zat Warna NBB dan IB}

Kurva standar NBB dan IB dibuat dengan cara mengukur absorbansi larutan NBB dan IB dengan variasi konsentrasi 10, 20, $30, \quad 40$ dan 50 ppm menggunakan spektofotometri UV-Vis pada panjang gelombang maksimum yang sudah didapatkan sebelumnya. Selanjutnya dibuat kurva hubungan antara konsentrasi dan absorbansi sehingga diperoleh persamaan regresinya.

\subsection{Penentuan Model Kinetika Adsorpsi}

Penentuan model kinetika adsorpsi NBB dan IB pada asam humat dilakukan dengan cara menginteraksikan $10 \mathrm{mg}$ asam humat dengan dengan $10 \mathrm{ml}$ larutan zat warna NBB/IB dengan konsentrasi awal yang sama pada kondisi $\mathrm{pH}$ optimum. $\mathrm{pH}$ optimum untuk kinetika adsorpsi NBB mengacu pada penelitian Prandini dan Rahmayanti [1]yaitu $\mathrm{pH}$ 2. Sementara itu, $\mathrm{pH}$ optimum untuk kinetika adsorpsi IB mengacu pada penelitian Santi dan Rahmayanti [2]yaitu pH 2. Campuran diaduk selama rentang waktu 0-90 menit kemudian disaring menggunakan kertas Whatman 42. Filtrat yang diperoleh dianalisis menggunakan spektrofotometer UV-Vis pada panjang gelombang maksimum NBB/IB. Model kinetika yang digunakan pada penelitian ini adalah model kinetika adsorpsi orde satu semu Lagergren dan orde dua semu Ho.

\subsection{Penentuan Model Isoterm Adsorpsi}

Penentuan model isoterm adsorpsi NBB dan IB pada asam humat dilakukan dengan cara menginteraksikan $10 \mathrm{mg}$ asam humat dengan $10 \mathrm{ml}$ larutan zat warna indigosol dengan konsentrasi variasi dari 10 , 20, 30, 40 dan $50 \mathrm{ppm}$ pada kondisi $\mathrm{pH}$ dan waktu optimum (30 menit untuk NBB dan 60 menit untuk IB). Campuran diaduk selama waktu optimum kemudian disaring menggunakan kertas Whatman 42. Filtrat yang diperoleh dianalisis secara spektrofotometri UV-Vis.

\section{Hasil Penelitian}

3.1. Panjang Gelombang Maksimum Zat Warna NBB dan IB Menggunakan Spektofotometri UV-Vis

Hasil pengukuran panjang gelombang maksimum larutan zat warna NBB dan IB pada penelitian ini disajikan pada Tabel 1 . Panjang gelombang maksimum ini digunakan untuk studi kinetika dan isoterm adsorpsi NBB dan IB pada asam humat.

Tabel 1. Data Panjang Gelombang Maksimum Zat Warna NBB dan IB

\begin{tabular}{cc}
\hline Zat Warna & $\begin{array}{c}\text { Panjang Gelombang Maksimum } \\
(\mathrm{nm})\end{array}$ \\
\hline NBB & 585 \\
\hline IB & 591 \\
\hline
\end{tabular}

\subsection{Kurva Standar Zat Warna NBB dan IB}

Penentuan kurvastandar zat warna NBB dan IB bertujuan untuk mendapatkan persamaan regresi yang akan digunakan dalam menentukan konsentrasi zat warna NBB dan IB yang teradsorpsi pada asam humat. Larutan standar NBB dan IB diukur pada panjang gelombang maksimum masing-masing. Kurva 
standar zat warna NBB dan IB disajikan pada Gambar 4.

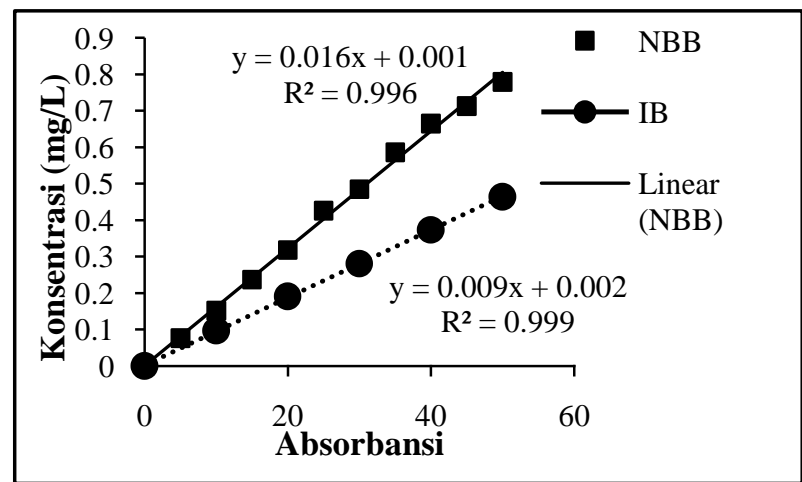

Gambar 4. Kurva standar zat warna NBB dan IB

\subsection{Studi Kinetika Adsorpsi}

Proses adsorpsi merupakan suatu proses kesetimbangan yang berlangsung dalam dua tahap. Tahap pertama adalah transport adsorbat ke permukaan adsorben, dan tahap kedua adalah adsorpsi adsorbat pada permukaan adsorben. Proses adsorpsi memiliki laju adsorpsi yangdipengaruhi oleh ukuran dan struktur molekul adsorbat, sifat dasar pelarut, dan sifat penyerapan adsorben. Laju adsorpsi dapat ditentukan dengan mengukur perubahan konsentrasi sebagai fungsi waktu dan menganalisisnya dengan analisis nilai $\mathrm{k}$ (konstanta laju adsorpsi)[14].

Model kinetika adsorpsi NBB dan IB pada HA hasil isolasi tanah gambut Kalimantan yang dipelajari adalah model kinetika orde satu semu Lagergren [15] dan model kinetika orde dua semu Ho [16]. Model kinetika orde satu semu Lagergren dinyatakan dengan persamaan (1).

$\operatorname{In}\left(\mathrm{q}_{\mathrm{e}}-\mathrm{q}_{\mathrm{t}}\right)=\ln \operatorname{In} \mathrm{q}_{\mathrm{e}}-\mathrm{k}_{1} \mathrm{t}$

Berdasarkan persamaan (1), besarnya konsentrasi NBB/IB yang teradsorpsi per unit massa adsorben HA pada waktu " $t$ " dinyatakan sebagai $\mathrm{q}_{\mathrm{t}}(\mathrm{mg} / \mathrm{g})$ dan besarnya konsentrasi $\mathrm{NBB} / \mathrm{IB}$ yang teradsorpsi per unit massa adsorben HA pada kesetimbangan telah tercapai dinyatakan dengan $\mathrm{q}_{\mathrm{e}}(\mathrm{mg} / \mathrm{g})$. Konstanta laju adsorpsi Lagergren dinyatakan sebagai $\mathrm{k}_{1}\left(\right.$ menit $\left.^{-1}\right)$.
Penerapan model kinetika Lagergren dilakukan dengan membuat kurva $\mathrm{t}$ (menit) versus In $\left(\mathrm{q}_{\mathrm{e}}-\mathrm{q}_{\mathrm{t}}\right)$ yang menghasilkan slope dan intersep, konstanta laju adsorpsi $\left(\mathrm{k}_{1}\right)=$ slope, dan jumlah NBB/IB yang teradsorpsi pada HA saat kesetimbangan diperoleh dari intersep, dimana intersep $=$ In $q_{e}$. Kurva adsorpsi NBB dan IB pada HA berdasarkan persamaan kinetika orde satu semu Lagergren disajikan pada Gambar 5.

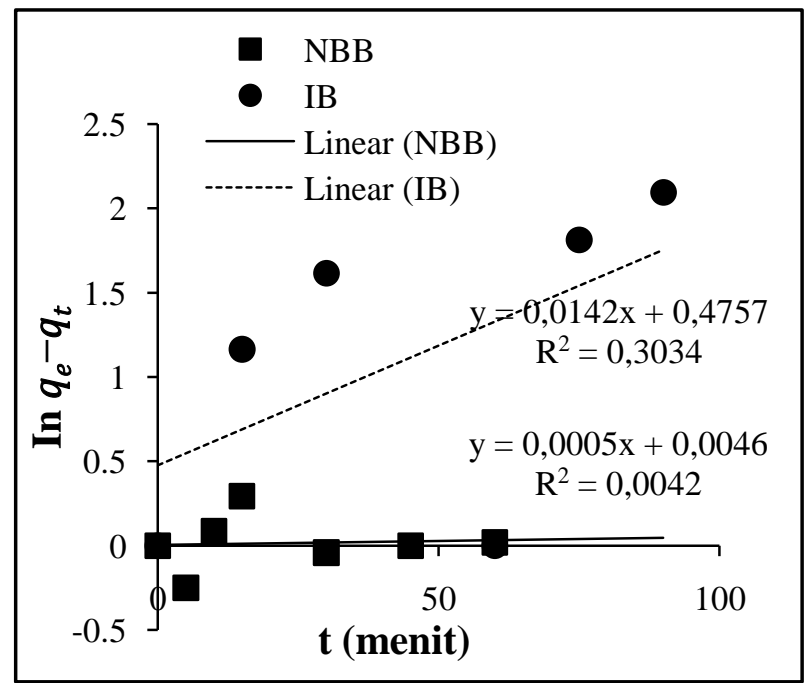

Gambar 5. Adsorpsi NBB dan IB pada HA berdasarkan persamaan kinetika orde satu semu Lagergren (suhu kamar, $\mathrm{pH}=2$ (NBB), $\mathrm{pH}=5$ (IB))

Adsorpsi NBB dan IB pada HA dilakukan pada suhu kamar dengan kondisi $\mathrm{pH}$ $=2$ untuk NBB dan $\mathrm{pH}=5$ untuk IB. Berdasarkan Gambar 5 diperoleh nilai $\mathrm{R}^{2}$ yang sangat kecil baik untuk adsorpsi NBB maupun IB pada HA. Dengan demikian, adsorpsi zat warna NBB dan IB pada HA tidak mengikuti model kinetika orde satu semu Lagergren. Kinetika orde satu semu banyak diasumsikan dari adanya laju aksi massa adsorpsi yang melibatkan difusi pada lapisan permukaan adsorben sebagai penentu utama laju adsorpsi. Artinya adsorpsi NBB dan IB pada HA pada penelitian ini tidak hanya ditentukan oleh proporsi adsorben HA saja. Dugaan lain adalah konsentrasi awal larutan NBB dan IB yang digunakan pada penelitian ini tidak berlebih dibandingkan ketersediaan situs aktif pada adsorben HA. Hal ini sesuai dengan yang disampaikan oleh Santosa [17] yang 
menyatakan bahwa model kinetika ini terbatas digunakan untuk adsorpsi dengan konsentrasi awal larutan adsorbat berlebih dibandingkan ketersediaan situs aktif pada adsorben.

Model kinetika orde dua semu Ho dinyatakan dengan persamaan (2).

$\frac{\mathrm{t}}{\mathrm{q}_{\mathrm{t}}}=\frac{1}{\mathrm{k}_{2} \mathrm{q}_{\mathrm{e}}^{2}}+\frac{1}{\mathrm{q}_{\mathrm{e}}}$

$\mathrm{k}_{2}$ merupakan konstanta laju adsorpsi Ho dengan satuan g/mg.menit.Konsentrasi NBB/IB yang teradsorpsi per unit satuan massa adsorben HA pada waktu " $t$ " dan pada kestimbangan tercapai dinyatakan dengan $\mathrm{q}_{\mathrm{t}}$ dan $\mathrm{q}_{\mathrm{e}}$ (dengan satuan $\mathrm{mg} / \mathrm{g}$ ). Penerapan model kinetika Ho dilakukan dengan membuat kurva $\mathrm{t}$ (menit) versus $\frac{\mathrm{t}}{\mathrm{q}_{\mathrm{e}}}$ yang menghasilkan slope $=\frac{1}{\mathrm{q}_{\mathrm{e}}}$ yang digunakan untuk menghitung kapasitas adsorpsi zat warna NBB/IB pada HA saat kesetimbangan $\left(\mathrm{q}_{\mathrm{e}}\right)$, dan intersep $=\frac{1}{\mathrm{k}_{2} \mathrm{q}_{\mathrm{e}}^{2}}$ yang digunakan untuk menghitung konstanta adsorpsi Ho $\left(\mathrm{k}_{2}\right)$. Laju adsorpsi awal (h) diperoleh dari nilai 1/intersep. Kurva adsorpsi NBB dan IB pada HA berdasarkan persamaan kinetika orde dua semu Ho disajikan pada Gambar 6.

Berdasarkan Gambar 6, nilai $\mathrm{R}^{2}$ pada kurva adsorpsi NBB dan IB pada HA berturutturut adalah 0,9668 dan 0,9988. Artinya adsorpsi NBB dan IB pada adsorben HA mengikuti model kinetika Ho. Model kinetika Ho mengasumsikan bahwa kapasitas adsorpsi proporsional terhadap jumlah situs aktif dari adsorben. Artinya, kapasitas adsorpsi NBB dan IB pada HA proporsional terhadap jumlah situs aktif adsorben HA [16]. Situs aktif yang terkandung dalam adsorben asam humat pada penelitian ini adalah $300 \mathrm{cmol} / \mathrm{kg}$ gugus $\mathrm{COOH}$ dan $275 \mathrm{cmol} / \mathrm{kg}$ gugus -OH [10]. Perbandingan parameter model kinetika adsorpsi Ho untuk adsorpsi NBB dan IB pada HA sajikan pada Tabel 1.

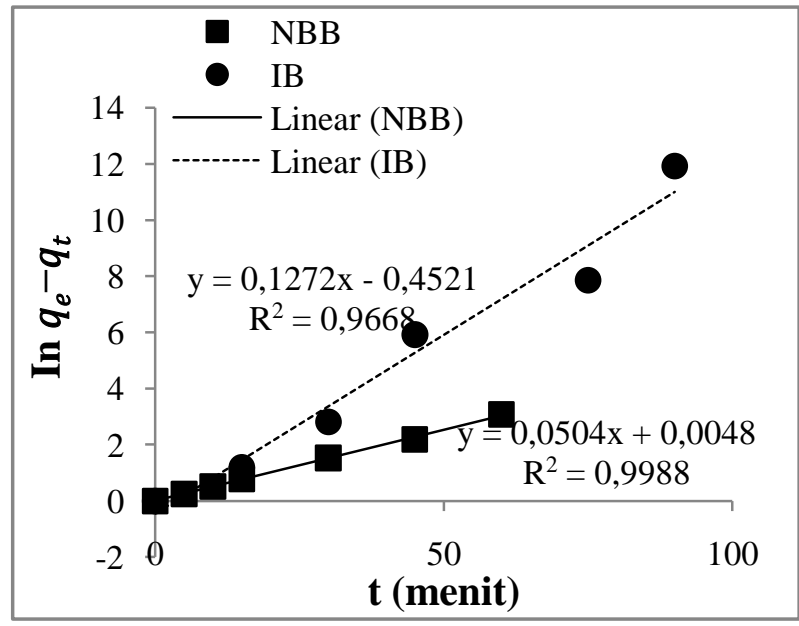

Gambar 6. Adsorpsi NBB dan IB pada HA berdasarkan persamaan kinetika orde dua semu Ho (suhu kamar, $\mathrm{pH}$ $=2(\mathrm{NBB}), \mathrm{pH}=5(\mathrm{IB}))$

Tabel 2.Perbandingan parameter model kinetika adsorpsi Ho untuk adsorpsi NBB dan IB pada HA Model kinetika orde dua semu Ho

\begin{tabular}{crrrr} 
& \multicolumn{4}{c}{ Model kinetika orde dua semu Ho } \\
\cline { 2 - 5 } Adsorbat & $\mathrm{R}^{2}$ & $\begin{array}{c}\mathrm{q}_{\mathrm{e}} \\
(\mathrm{mg} / \mathrm{g})\end{array}$ & $\begin{array}{c}\mathrm{h} \\
(\mathrm{mg} / \mathrm{g} . \text { menit })\end{array}$ & $\begin{array}{c}\mathrm{k} \\
\left(\frac{\mathrm{g}}{\mathrm{mg} \cdot \mathrm{menit}}\right)\end{array}$ \\
\hline NBB & 0,999 & 19,84 & 208,33 & 0,5292 \\
\hline IB & 0,967 & 7,86 & 2,21 & 0,0358 \\
\hline
\end{tabular}

Berdasarkan Tabel 2, terlihat bahwa konstanta laju adsorpsi (k) dan laju adsorpsi awal (h) untuk adsorpsi NBB pada HA lebih tinggi dibandingkan konstanta adsorpsi IB pada HA. Begitu juga dengan kapasitas adsorpsi NBB pada saat kesetimbangan lebih tinggi dibandingkan dengan kapasitas adsorpsi IB pada saat kesetimbangan dengan waktu optimum adsorpsi $\mathrm{NBB}$ pada $\mathrm{HA}=30$ menit dan adsorpsi IB pada $\mathrm{HA}=60$ menit.Hal ini diduga dipengaruhi oleh perbedaan stuktur molekul NBB dan IB. Dugaan interaksi yang terjadi antara NBB dan IB dengan HA adalah melalui interaksi elektrostatik antara gugus $\mathrm{COOH}$ dan -OH HA yang terprotonasi dengan dengan gugus $-\mathrm{SO}_{3}{ }^{-} \mathrm{NBB}$ dan $\mathrm{IB}$ dan melalui ikatan hidrogen $[5,6]$. Jika dilihat dari struktur molekul NBB dan IB (Gambar 2 dan 3), terlihat bahwa zat warna NBB memiliki lebih banyak gugus aktif seperti -N=N. - $\mathrm{NO}_{2}, \mathrm{NH}_{2}$, $\mathrm{OH}$ yang memungkinkan terjadinya ikatan hidrogen antara NBB dengan atom hidrogen gugus - $\mathrm{COOH}$ dan -OH dari adsorben HA. Hal inilah yang menyebabkan interaksi antara 
NBB dengan HA lebih cepat mencapai kesetimbangan dibandingkan dengan interaksi antara IB dan HA. Ilustrasi interaksi antara NBB dengan HA disajikan pada Gambar 7.

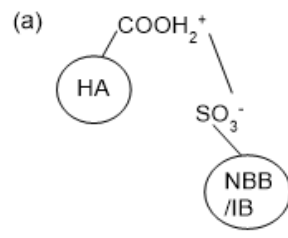

(b)
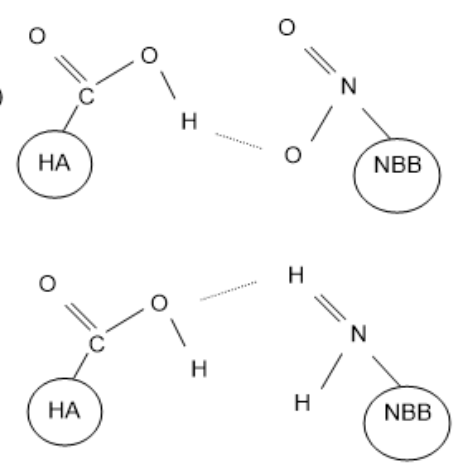

Gambar 7. Ilustrasi interaksi antara NBB dengan HA melalui (a) ikatan elektrostatik (b) ikatan hidrogen

\subsection{Studi Isoterm Adsorpsi}

Isoterm adsorpsi dipelajari untuk menentukan kapasitas adsorpsi NBB/IB pada permukaan padatan (adsorben HA) pada temperatur konstan. Model isoterm adsorpsi yangdigunakan pada penelitian ini untuk menjelaskan pola isoterm adsorpsi adalah isoterm Langmuir[18] dan Freundlich[19].

Model Isoterm adsorpsi Langmuir dinyatakan dengan persamaan (3).

$\frac{\mathrm{C}_{\mathrm{e}}}{\mathrm{q}_{\mathrm{e}}}=\frac{1}{\mathrm{q}_{\max } \mathrm{K}_{\mathrm{L}}}+\frac{\mathrm{C}_{\mathrm{e}}}{\mathrm{q}_{\max }}(3)$

Penjelasan persamaan (3) adalah sebagai berikut: $\mathrm{q}_{\mathrm{e}}$ merupakan jumlah zat warna yang teradsorpsi pada keadaan kesetimbangan (mg/g), $\mathrm{C}_{\mathrm{e}}$ adalah konsentrasi ion logam bebas dalam larutan pada keadaan kesetimbangan (mg/L). Kapasitas adsorpsi maksimum dinyatakan sebagai $\mathrm{q}_{\max }(\mathrm{mg} / \mathrm{g})$ dan konstanta Langmuir ( $\mathrm{L} / \mathrm{mol})$ yang berhubungan dengan energi adsorpsi dinyatakan sebagai $\mathrm{K}_{\mathrm{L}}$.

Berdasarkan persamaan (3), jika dibuat kurva $\mathrm{C}_{\mathrm{e}} / \mathrm{q}_{\mathrm{e}}$ terhadap $\mathrm{C}_{\mathrm{e}}$ maka akan didapatkan suatu garis lurus. Dari persamaan garis lurus tersebut, akan diperoleh slope dan intersep. Nilai $\mathrm{K}_{\mathrm{L}}$ merupakan 1/slope, sedangkan intersep merupakan nilai $1 / \mathrm{q}_{\max }$.

Model isoterm Freundlich dapat dinyatakan dengan persamaan (4).

$\log \mathrm{q}_{\mathrm{e}}=\log \mathrm{K}_{\mathrm{F}}+1 / \mathrm{n} \log \mathrm{C}_{\mathrm{e}}$

Penjelasan persamaan (4) adalah sebagai berikut: jumlah spesies teradsorpsi per gram adsorben pada kesetimbangan dinyatakan sebagaibq $(\mathrm{mg} / \mathrm{g}) . \quad \mathrm{C}_{\mathrm{e}}$ adalah konsentrasi ion bebas dalam larutan pada keadaan kesetimbangan $(\mathrm{mg} / \mathrm{g})$, dan $\mathrm{K}_{\mathrm{F}}$ adalah konstanta Freundlich yang berhubungan dengan kapasitas adsorpsi dan $1 / n$ adalah faktor heterogenitas.Nilai $\mathrm{K}_{\mathrm{F}}$ dan $\mathrm{n}$ akan diperoleh dari slope dan intersep persamaan garis lurus kurva $\log \mathrm{q}_{\mathrm{e}}$ versuslog $\mathrm{C}_{\mathrm{e}}$.

Kurva adsorpsi NBB dan IB pada HA berdasarkan persamaan Isoterm Langmuir dan Freundlich berturut-turut disajikan pada Gambar 8 dan 9. Berdasarkan Gambar 8 dan 9, nilai $\mathrm{R}^{2}$ kurva adsorpsi $\mathrm{NBB}$ dan IB pada HA berdasarkan persamaan Isoterm Freundlich berturut-turut adalah 0,7394 dan 0,6888 . Sementara itu, nilai $\mathrm{R}^{2}$ kurva adsorpsi NBB dan IB pada HA berdasarkan persamaan Isoterm Langmuir berturut-turut adalah 0,9963 dan 0,9971. Dilihat dari nilai $\mathrm{R}^{2}$ yang diperoleh, dapat dikatakan bahwa adsorpsi NBB dan IB pada HA mengikuti model isoterm Langmuir. Artinya adsorpsi NBB dan IB pada HA merupakan adsorpsi satu lapis (monolayer) pada permukaan HA yang seragam (homogen) dengan energi ałtsorpsi sama untuk semua situs aktif tanpa memperhatikan derajat penutupannya.Molekul adsorbat NBB/IB dianggap tidak saling berinteraksi satu sama lain dan semua proses adsorpsi terjadi dengan mekanisme yang sama. Jika semua situs aktif pada permukaan adsorben HA telah ditutupi oleh NBB/IB, maka proses adsorpsi selanjutnya akan terhalangi.Perbandingan parameter model isoterm adsorpsi NBB dan IB pada HA disajikan pada Tabel 3 dan 4. 


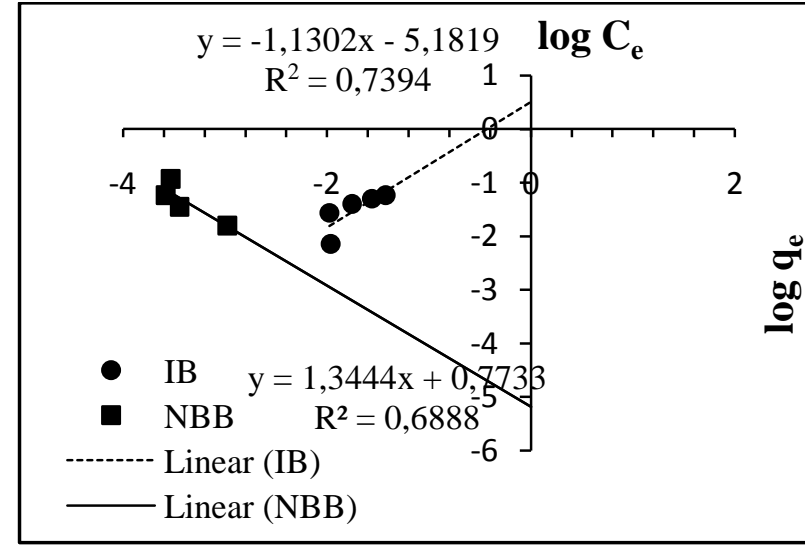

Gambar 8. Adsorpsi NBB dan IB pada HA berdasarkan persamaan Isoterm Freundlich (suhu kamar, $t=45$ menit (NBB), $\mathrm{t}=60$ menit (IB), $\mathrm{pH}=2(\mathrm{NBB}), \mathrm{pH}=5$ (IB))
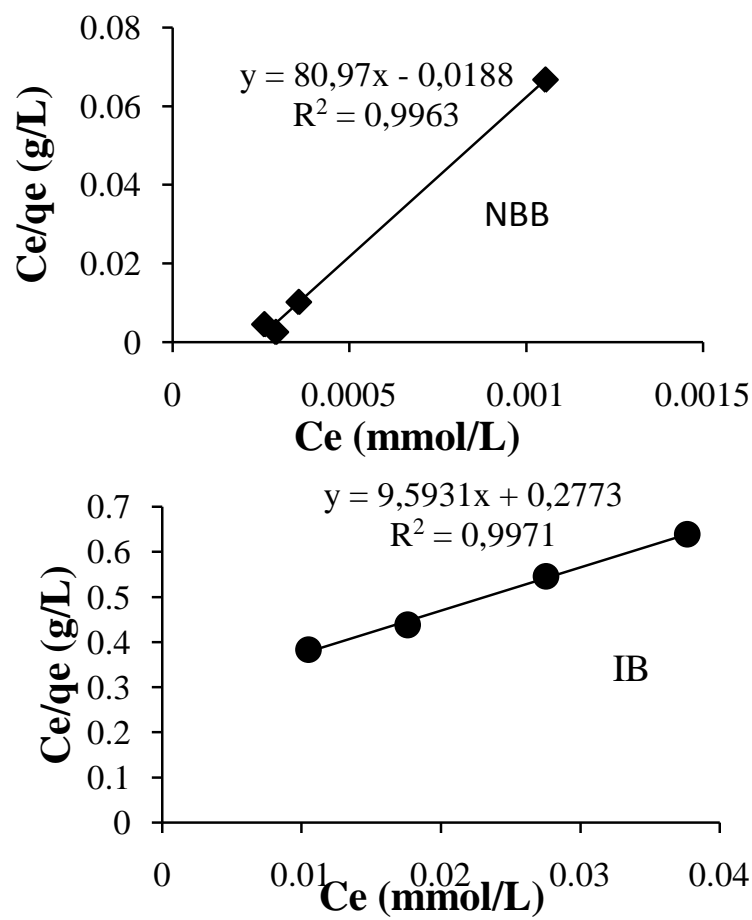

Gambar 9. Adsorpsi NBB dan IB pada HA berdasarkan persamaan Isoterm Langmuir (suhu kamar, $\mathrm{t}=45$ menit (NBB), $\mathrm{t}=60$ menit (IB), $\mathrm{pH}=2(\mathrm{NBB}), \mathrm{pH}=5(\mathrm{IB}))$

Berdasarkan model isoterm adsorpsi Langmuir yang disajikan pada Tabel 3, kapasitas adsorpsi maksimum NBB pada HA lebih rendah dibandingkan kapasitas adsorpsi maksimum IB pada HA. Artinya, menurut model isoterm Langmuir, HA lebih baik sebagai adsorben zat warna IB dibandingkan zat warna NBB meskipun laju reaksi adsorpsi NBB pada HA lebih tinggi dibandingkan laju reaksi adsorpsi IB pada HA. Sementara itu energi adsorpsi NBB pada HA lebih tinggi dibandingkan energi adsorpsi IB pada HA. Artinya energi yang dihasilkan oleh adsorpsi 1 mol zat warna NBB pada HA lebih tinggi dibandingkan energi yang dihasilkan oleh adsorpsi 1 mol zat warna IB pada HA. Hal ini menunjukkan bahwa ikatan yang terbentuk antara NBB dengan HA lebih kuat dibandingkan ikatan yang terbentuk antara IB dan HA.

Tabel 3.Perbandingan Parameter model isoterm adsorpsi Langmuir NBB dan IB pada HA

\begin{tabular}{ccccc}
\hline & \multicolumn{4}{c}{ Parameter Langmuir } \\
\cline { 2 - 5 } Adsorbat & $\begin{array}{c}\mathbf{q}_{\text {max }} \\
(\mathbf{m o l} / \mathbf{g})\end{array}$ & $\begin{array}{c}\mathbf{K}_{\mathbf{L}} \\
(\mathbf{L} / \mathbf{m o l})\end{array}$ & $\begin{array}{c}\mathbf{E}_{\mathbf{a d s}} \\
\mathbf{( k J /} / \\
\mathbf{m o l})\end{array}$ & $\mathbf{R}^{\mathbf{2}}$ \\
\hline $\begin{array}{c}\text { NBB/HA } \\
\text { penelitian } \\
\text { ini) }\end{array}$ & $0,12 \times 10^{-4}$ & $4,3 \times 10^{6}$ & 38,5 & 0,996 \\
\hline $\begin{array}{c}\text { IB/HA } \\
\text { (penelitian } \\
\text { ini) }\end{array}$ & $1,04 \times 10^{-4}$ & $0,3 \times 10^{6}$ & 26,3 & 0,997 \\
\hline $\begin{array}{c}\text { NBB/Fe } \\
\mathrm{O}_{4}-\mathrm{HA}[1]\end{array}$ & $24,1 \times 10^{-4}$ & $0,059 \times 10^{6}$ & 26,6 & 0,996 \\
\hline
\end{tabular}

Tabel 4.Perbandingan Parameter model isoterm adsorpsi Freundlich NBB dan IB pada HA

\begin{tabular}{cccc}
\hline \multirow{2}{*}{ Adsorbat } & \multicolumn{3}{c}{ Parameter Freundlich } \\
\cline { 2 - 4 } & $\mathbf{K}_{\mathbf{F}}(\mathbf{m o l} / \mathbf{g})$ & $\mathbf{n}$ & $\mathbf{R}^{\mathbf{2}}$ \\
\hline $\begin{array}{c}\text { NBB } \\
\text { (penelitian } \\
\text { ini) }\end{array}$ & $6,6 \times 10^{-9}$ & $-0,8848$ & 0,739 \\
\hline $\begin{array}{c}\text { IB } \\
\text { (penelitian } \\
\text { ini) }\end{array}$ & $5,9 \times 10^{-3}$ & 0,7483 & 0,688 \\
\hline
\end{tabular}

\section{Kesimpulan}

Penelitian ini sudah berhasil mengaplikasikan asam humat sebagai adsorben zat warna NBB dan IB. Adsorpsi NBB dan IB pada HA mengikuti model kinetika orde dua Ho, dengan konstanta laju reaksi adsorpsi NBB pada HA lebih tinggi dibandingkan konstanta laju reaksi adsorpsi IB pada HA. Studi isoterm reaksi menunjukkan bahwa adsorpsi NBB dan IB pada HA mengikuti model isoterm Langmuir dengan kapasitas adsorpsi maksimum NBB dan IB 
pada HA berturut-turut adalah $0,12 \times 10^{-4}$ dan $1,04 \times 10^{-4} \mathrm{~mol} / \mathrm{g}$.

\section{Saran}

Diperlukan adanya penelitian lebih lanjut terkait model interaksi yang lebih detail antara NBB dan IB pada HA menggunakan insrumen yang lebih lengkap dan detail.

\section{Ucapan Terima Kasih}

Penulis mengucapkan terimakasih kepada Laboratorium Kimia UIN Sunan Kalijaga Yogyakarta untuk semua fasilitas dan layanan yang diberikan.

\section{Daftar Pustaka}

[1] M. Rahmayanti, E. Yunita, N. F. Y. Putri, Study of Adsorption-Desorption on Batik Industrial Dyes (Naphthol Blue Black) on Magnetite Modified Humic Acid (HA$\mathrm{Fe}_{3} \mathrm{O}_{4)}$,Jurnal Kimia Sains dan Aplikasi, vol. 23, no. 7, pp. 244-248, 2020.

[2] H. Ferkous, O. Hamdaoui, S. Merouani. Sonochemical degradation of naphthol blue black in water: Effect of operating parameters. Ultrasonic Sonochemistry. vol. 26. pp. 40-47. 2015.

[3] M.A. Brown, S.C. De Vito, Predicting azo dye toxicity, Crit. Rev. Environ. Sci. Technol. Vol. 23, pp. 249-324, 1993.

[4] S.L.H. Rebelo, M. Linhares, M.M.Q. Simões, A.M.S. Silva, M.G.P.M.S. Neves, J.A.S. Cavaleiro, C.Freire, Indigo dye production by enzymatic mimicking based on an iron (III) porphyrin. J. Catal., vol. 315, pp. 3340, 2014.

[5] M. N. Prandini dan M. Rahmayanti, Effect $\mathrm{pH}$ Adsorption of Naphtol Dye Using Humic Acid Adsorbent Result of Peat Isolation from Kalimantan, in Proceeding International Conference Science and Engineering 3, 2020, pp. 147-151.

[6] G. C. Santi dan M. Rahmayanti, Effect of Solution $\mathrm{pH}$ to Indigosol Blue Adsorption on Humic Acid Isolated from Kalimantan Peat Oil, in Proceeding International Conference Science and Engineering 2, 2019, pp. 193-195.

[7] G. W. Ekowati dan M. Rahmayanti, Kajian Desorpsi Zat Warna Indigosol Blue Dari
Adsorben Humin Hasil Isolasi Tanah Gambut Riau, Sumatera, Analit: Analytical and Environmental Chemistry, vol. 4, no. 2, pp. 68-75, 2019.

[8] S. R. Fuadah dan M. Rahmayanti, AdsorpsiDesorpsi Zat Warna Naftol Blue Black Menggunakan Adsorben Humin Hasil Isolasi Tanah Gambut Riau, Sumatera, Analit: Analytical and Environmental Chemistry, vol. 4, no. 2, pp. 59-67, 2019.

[9] W. N. Latifah dan M. Rahmayanti, Desorption of Indigosol Blue from Humic Acid Coated $\mathrm{Fe}_{3} \mathrm{O}_{4}$ Particles, in Proceeding International Conference Science and Engineering 3, 2020, pp. 169-170

[10] M. Rahmayanti, E. Yunita , M. N. Prandini, Isolasi Asam Humat dari Tanah Gambut Sumatera dan Kalimantan dan Analisis Kandungan Gugus Fungsionalnya, Integrated Lab Journal, vol. 7, no. 2, pp. 132-139, 2019.

[11] M. Rahmayanti, S.J. Santosa, Sutarno. Mechanisms of Gold Recovery From Aqueous Solutions Using Gallic acidmodified Magnetite Particles Synthesized Via Reverse Co-precipitation Method. International Journal of ChemTech Research. vol. 9, no. 4, pp. 446-452, 2016.

[12] M. Rahmayanti, G. Abdillah, S. J.i Santosa, Sutarno, Application of Humic Acid Isolated From Kalimatan Peat Soil Modifying Magnetite for Recovery of Gold, Jurnal Bahan Alam Terbarukan, vol. 8 , no. 2, pp. 77-83, 2020.

[13] M. Rahmayanti, S. J. Santosa, Sutarno, Comparative Study on the Adsorption of [AuCl] $]^{-}$onto Salicylic Acid and Gallic Acid Modified Magnetite Particles, Indonesian Journal of Chemistry, vol. 16, no. 3, pp. 329-337, 2016.

[14] Dexin Fang, Xianquan Zhuang, Liping Huang, Qian Zhang, Qiushi Shen, Lei Jiang, Xiaoyi Xu, Fangying Ji,Developing the new kinetics model based on the adsorption process: From fitting to comparison and prediction, Science of the Total Environment, vol. 723, no.138490, pp.1-11, 2020.

[15] Y.S. Ho, Citation Review of Lagergren Kinetic Rate Equation on Adsorption Reactions,Journal Scientometrics, vol. 59, pp. 171-177, 2004. 
[16] Y.S.Ho, dan G.McKay, Pseudo-second Order Model for Sorption Processes. Procedia Biochemistry, vol. 34, no. 5, pp. 451-465, 1999.

[17] Santosa, Sri Juari. Sorption Kinetics of Cd (II) Species on Humic Acid-Based Sorbent. Clean Journal Soil Air Water, vol. 42, no. 6, pp. 760-766, 2014.

[18] I. Langmuir, The constitution and fundamental properties of solids and liquids, Journal of The American Chemical Society, vol. 38, no. 11, pp. 2221-2295, 1916.

[19] H.M.F. Freundlich, Tiber die adsorption in losungen, Zeitschrift für Physikalische Chemie, vol. 57, pp. 385-490, 1906.

[20] Riyanto, Didik. 1995. Press Batik: Batik Tulis - Batik Cap - Batik Printing. Solo: CV Aneka. 